\title{
Quantification of water related soil erosion in the transboundary basin of the Bia (West Africa)
}

\author{
N'diaye Edwige Hermann Meledje ${ }^{1}$, Kouakou Lazare Kouassi ${ }^{1,2}$, and Yao Alexis N'Go ${ }^{3}$ \\ ${ }^{1}$ Marine Geology, Sedimentology and Environment Laboratory, Center of Ecology Research, University \\ Nangui Abrogoua, Abidjan, 225, Ivory Coast \\ ${ }^{2}$ Technical Sciences and Environment Laboratory, University Lorougnon Guédé, Daloa, 225, Ivory Coast \\ ${ }^{3}$ Geosciences and Environment Laboratory, University Nangui Abrogoua, Abidjan, 225, Ivory Coast
}

Correspondence: N’diaye Edwige Hermann Meledje (meledjendiay@yahoo.fr)

Published: 16 November 2021

\begin{abstract}
In view of the complexity of the phenomenon of water related soil erosion in the Bia catchment area, linked to a large heterogeneity of soils, to a very scattered and in some places non-existent vegetation cover, and to a poorly distributed precipitation in both space and time, a mapping test of the "specific erosion" random variable is undertaken. The mapping of the intensity of the erosion hazard was carried out using the Universal Soil Loss Model (USLE). The map shows that the basin is generally characterized by relatively moderate erosion rates with an average erosion rate of $16 \mathrm{t} / \mathrm{ha} /$ year.
\end{abstract}

\section{Introduction}

Erosion is a complex process. In Côte d'Ivoire, few studies have focused on water erosion, particularly in the Bia basin. However, population growth, land clearing and intensification of agriculture would lead to degradation of plant cover, ploughing, deterioration of soil aggregates, loss of organic matter, soil compaction, loss of soil biota and subsequent increases in runoff and soil erosion (on-site damages). The transport of sediment resulting in nutrient inputs accelerates the process of silting, silting and eutrophication of lakes (offsite damages) (Kouassi et al., 2013). In light of these negative consequences, the phenomenon of erosion is of particular interest for the economic development of countries (Raissouni, 2011). However, quantification of sediment input into the fluvial system remains difficult due to the temporal and spatial variability of the hydrological regime coupled with a lack of available data related to it. Modelling erosion phenomena and solid transport will be better addressed. It should be contextualized by measurements. In this sense, erosion modelling and mapping has now become a necessity for decision makers in order to be able to target areas of major risk and seek appropriate solutions. The integration of existing models with methods such as remote sensing and geographic information systems has made it possible to minimize financial costs and save time for risk mapping and consequently, targeted and rapid response. In this context, this study aims to use a universal soil loss equation (USLE) based model integrated under a Geographical Information System to quantify and map the risk of water erosion over the Bia watershed

\section{Presentation of study area}

The Bia basin is a transboundary watershed between Côte d'Ivoire and Ghana (Fig. 1). This basin has an area of about $9500 \mathrm{~km}^{2}$. the Bia River flowed entirely under dense forest with an average flow of $82 \mathrm{~m}^{3} \mathrm{~s}^{-1}$. The region receives an average annual rainfall of about $1450 \mathrm{~mm}$. The extreme south is occupied by very leached ferralitic soils. The digital elevation model (DEM) shows that about $20 \%$ of the total area of the basin is between 76 and $111 \mathrm{~m}$. The highest points in the center exceed $600 \mathrm{~m}$. In the southern part of the sub-basin, the elevation is below $200 \mathrm{~m}$. The average longitudinal slope is $3.5 \%$. Slopes greater than $15^{\circ}$ represent $11.07 \%$ of the Bia watershed area, slopes less than $15^{\circ}$ represent $88.92 \%$. The average longitudinal slope is $3.5 \%$. The agriculture is varied and include palm trees, rubber trees, coffee trees, cocoa trees and banana trees. These crops are in the form of agro-industrial plantations 


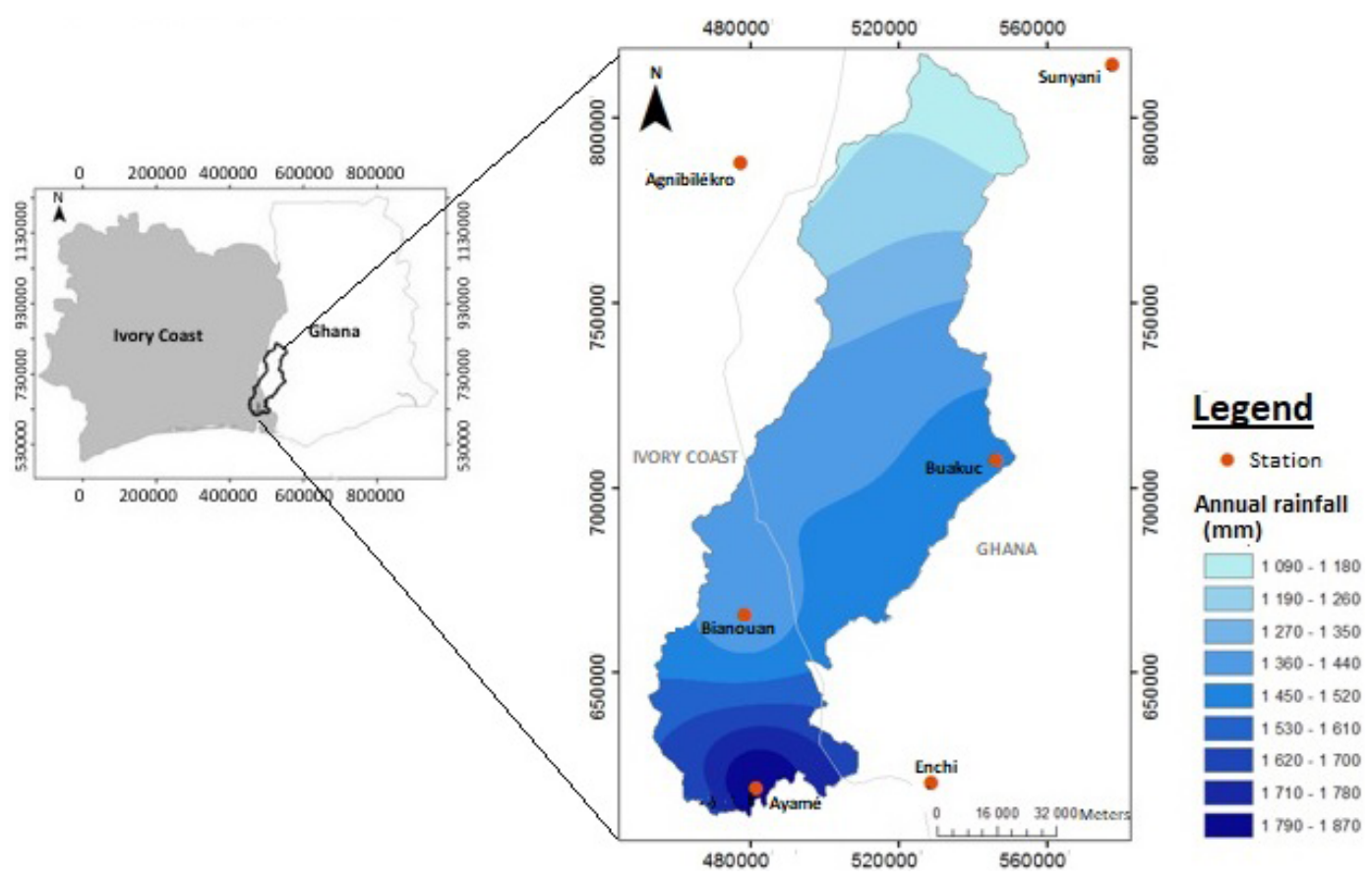

Figure 1. Situation map of the Bia basin.

\section{Material and methods}

\subsection{Data Acquisition and Processing}

The monthly rainfall data from six stations (Bianouan, Ayamé, Agnibilekro, Sunyani, Buakuc, Enchi) used in this study cover the period from 1990 to 2009. The data from the two agencies responsible for the rainfall network namely SODEXAM in Ivory Coast and the Department of Meteorological Services (Meteorological Services Department) in Ghana (Fig. 1).

Satellite images of the study area are of two types:

- The Shuttle Radar Topography Mission (SRTM) image of N05W004 coordinates, from 11 to 22 February 2000, from Space Shuttle Endeavour (STS-99), obtained from ftp://eosrp01u.ecs.nasa.gov/srtm/version1/ Africa (last access: 1 January 2021) was used. It was used to produce a digital elevation model (DEM) with a resolution of $30 \mathrm{~m}$ and the slope map

- Landsat ETM+ images, scenes 195-056 and 195-055, 14 March 2003, provided by http://earthexplorer.usgs. gov/ (last access: 1 January 2021). Its operation led to the characterization of land use (Fig. 2a) and land cover (Fig. 2b).

\subsection{Identification of Potential Erosion Areas}

Modelling of the process of water related soil erosion was performed using the Universal Soil Loss Equation (USLE) model of Wischmeier and Smith (1978) and modified by Renard et al. (1997). Erosion (A), expressed in t/ha/year, is the product of 5 factors (Eq. 1 and Fig. 3):

$A=R K L S C P$,

Where

- Rainfall erosivity factor $R$ (in $\mathrm{MJ} \mathrm{mm}$ (hah year) ${ }^{-1}$ ): The factor $R$ was calculated (Eq. 2) for six (6) stations in the region using the Arnoldus (1980) formula, adapted to tropical conditions. The formula takes into consideration only the average monthly $(p)$ and annual $(P)$ rainfall;

$R=\sum_{n=1}^{12}\left(\frac{p^{2}}{P}\right)$

- Soil erodibility factor $K$ (in $\mathrm{th} \mathrm{MJ}^{-1} \mathrm{~mm}^{-1}$ ): The $K$ factor was calculated using the texture triangle (Brown, 2003) and the matching table (Stone and Hilborn, 2000), thus allowing the soil erodibility values to be deduced from the texture.

- The topographic factor LS (dimensionless) represents the combination of "L" Slope length factor and "S" steepness factor. A depression less DEM is required to 


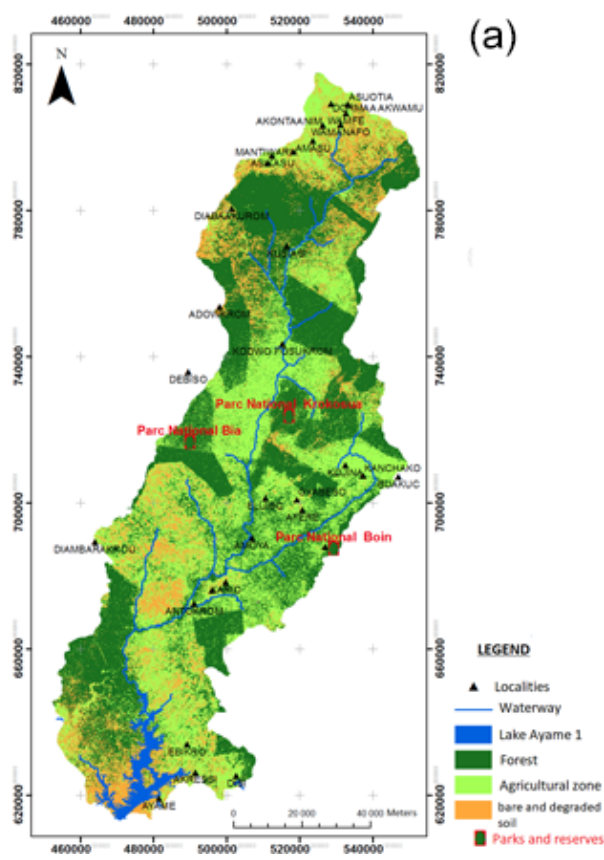

(b)

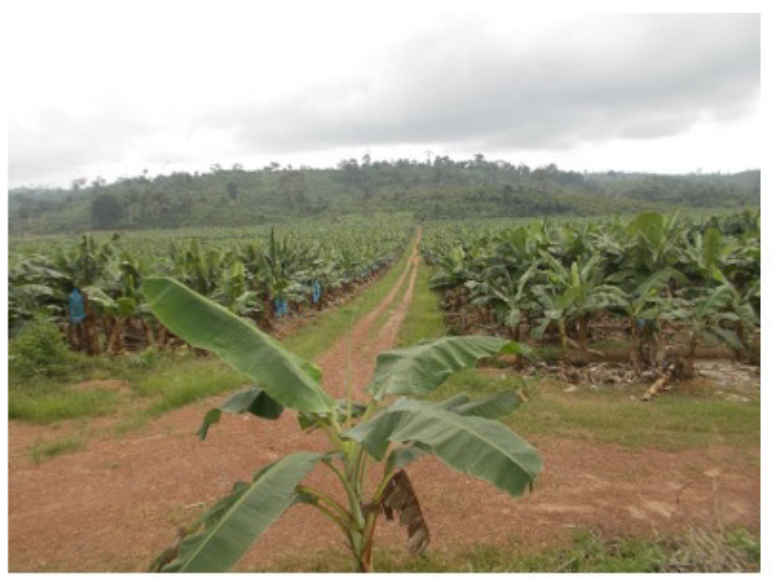

Figure 2. (a) Land cover and (b) land use of the Bia basin.

perform the necessary steps in finding the LS factor in which there are no sinks present. A $30 \mathrm{~m}$ spatial resolutions digital elevation model (DEM) was used to generate slope which was derived from the ASTER (GDEM). "Spatial Analyst Tool > Surface Slope" and "ArcHydro Tool" in ArcGIS 10.2 environment were applied for subsequent steps in calculating LS factor. Finally, spatially distributed value was determined using an equation proposed by Kumar et al. (2016) as in Eq. (3):

$\mathrm{LS}=(\text { flow acc } \times[\text { cell size }] / 22.1)^{0,4}$

$\left((\operatorname{Sin}(\text { Slope in } \operatorname{deg} \times 0.01745) / 0.09)^{1,4}\right) \times 1.4$

The parameters "slope_degree" and "flow acc" represent respectively the slope map and the flow accumulation map of the Bia basin

- Cover and management factor $C$ (dimensionless)

The value of the $C$-factor is estimated by the Normalized Difference Vegetation Index (NDVI). The NDVI calculation was based on the following formula (Gitas et al., 2009; Durigon et al., 2014) following Eq. (4):

$\mathrm{NDVI}=(\mathrm{PIR}-R) /(\mathrm{PIR}+R)$

PIR: the reflection of the near infrared portion of the electromagnetic spectrum and $R$ : the reflection in the visible spectrum.

The $C$-factor map is generated using the regression line found using the Arcgis10 Spatial Analysis module following
Eq. (5).

$C=\exp (-a \mathrm{NDVI} /(\beta-\mathrm{NDVI}))$

where $\alpha, \beta$ : parameters determining the shape of the NDVI$C$ curve.

Support and conservation practices factor $P$ (dimensionless): Slope percentage map was prepared using "Spatial Analyst Tool > Surface Slope" in GIS environment using DEM which was derived from the ASTER GDEM. According to cultivation method and slope, the following $P$ factor values were used as described by Shin (1999) cited by Kumar et al. (2016).

\section{Results}

\subsection{Data Acquisition and Processing}

The correspondence between the soil texture and the soil erosion revealed the most erodible soils in the catchment area (Fig. 3a). The $K$-factor ranges from 0 to $0.25 \mathrm{th} \mathrm{MJ}^{-1} \mathrm{~mm}^{-1}$, for soils most susceptible to erosion. The most erosible soils correspond to lithosols in the Ayamé region in the northen part of the study area, around Lake Ayamé, in the extreme South and in the ferruginous soil strip between the Sayero, Abum and Buakuc regions in the North (Fig. 3a). The highest $R$ values are located in the southern part of the basin, in Côte d'Ivoire with about $1160 \mathrm{MJ} \mathrm{mm}$ (ha h year) $^{-1}$, while the low values are located in the northern part of the study area (Fig. 3b). The relatively flat topography of the Bia watershed naturally implies a distribution of LS values between 0 and 100. The lowest values are in 

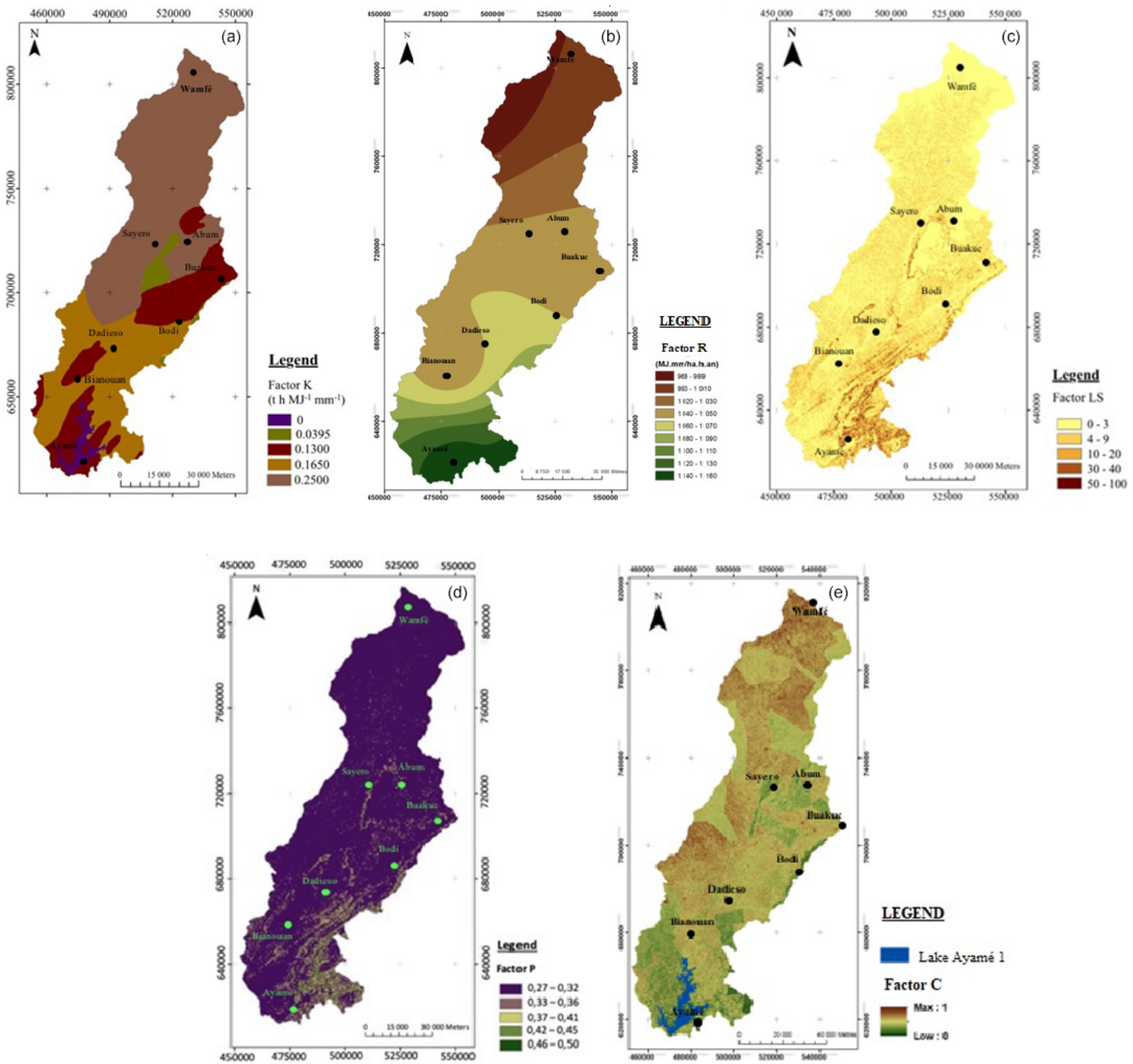

Figure 3. The different erosion factors of the Bia catchment area: (a) Soil erodibility factor $K$ - (b) Rainfall erosivity factor $R-$ (c) Topographical factor LS - (d) Support and conservation practices factor $P-(\mathbf{e})$ Land cover factor $C$.

the north and the highest in the south. The average factor over the entire watershed is estimated at 3.3 (Fig. 3c). Most of the basin is characterized by $C$-factor values greater than 0.8. These areas are bare soil or fallow. The second largest class consists of values ranging from 0.6 to 0.7 in the South and South-West and are associated with large grain and forage crops. Areas with values of less than 0.6 are generally covered by forests (parks and reserves). Bare soils account for about $10.47 \%$ of the study area, without taking into account areas of low vegetation cover (Fig. 3e). The values of anti-erosion practices are between 0.27 and 0.5 (Fig. 3d) reflecting the strip farming on the basin.

\subsection{Soil Loss and Soil Erosion Sensitivity}

Figure 4a presents a quantitative map with classes between 0 and $>1600 \mathrm{t} / \mathrm{ha} /$ year, with an average loss of $16 \mathrm{t} / \mathrm{ha} /$ year. The most sensitive areas of water related soil erosion, represent $189.41 \mathrm{~km}^{2}$ (2.04\% of the catchment) and can deliver up to $1631 \mathrm{t} / \mathrm{ha} /$ year of materials. At the watershed level, 29.43 million t/year of soil can potentially be removed and are therefore likely to contribute to current sediment flow dynamics. The statistical distribution (Fig. 4b) shows that $84.92 \%$ of the area of the Bia watershed reveals a low to moderate sensitivity to erosion while $2.04 \%$ a very high sensitivity (greater than $150 \mathrm{t} / \mathrm{ha} /$ year). Through comparisons with maps of different factors, the sensitivity map shows low erosion in the Central-West (very low slope areas), NorthEast (forests) of the basin, and moderate erosion in the West and North. Very high erosion occupies only limited and con- 

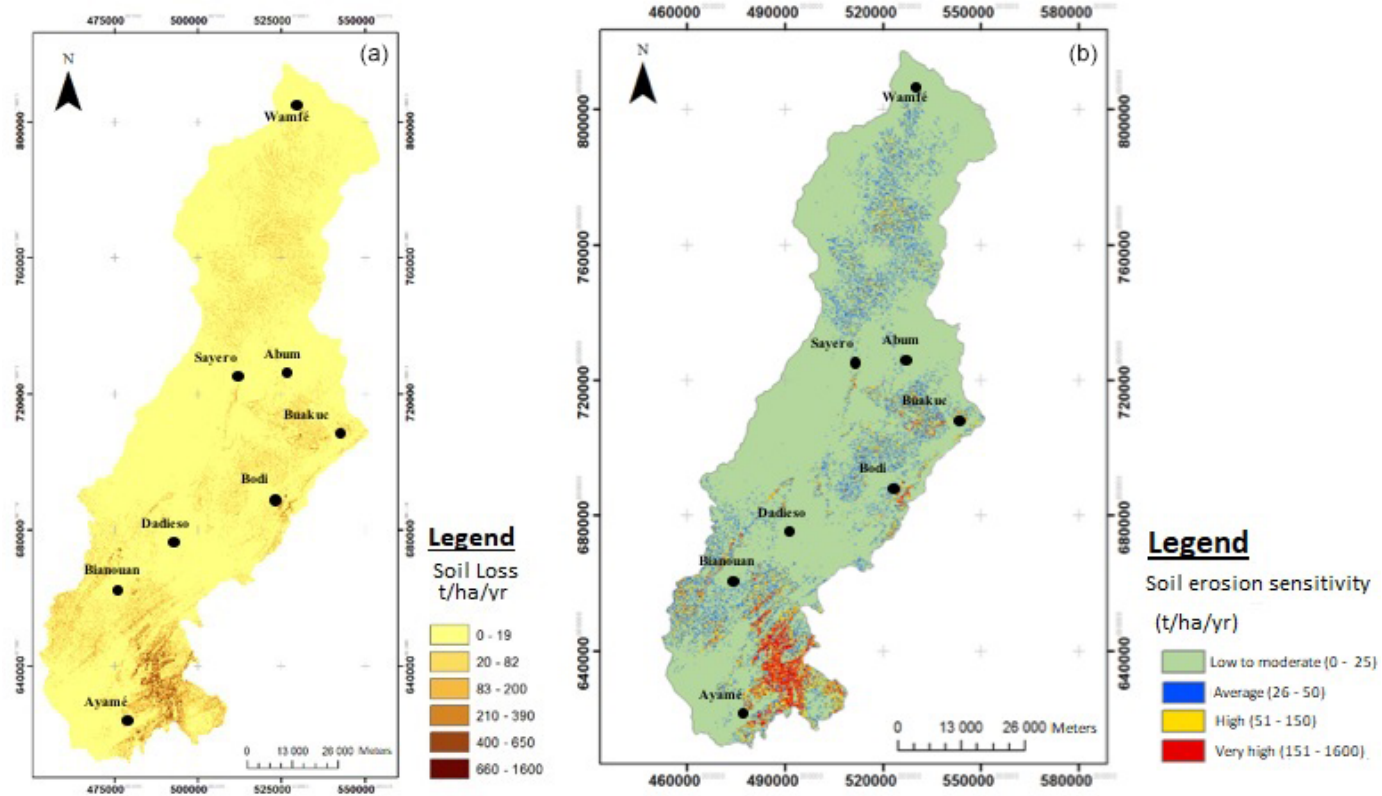

Figure 4. The different erosion factors of the Bia catchment area: (a) Soil loss - (b) Soil erosion sensitivity.

centrated areas, especially at the southern end of the basin where there is bare land on relatively steep slopes and high relief.

\section{Discussion and conclusion}

The Bia watershed is subject to strong climatic aggressiveness with an average of $1040 \mathrm{MJ} \mathrm{mm}$ (ha h year) ${ }^{-1}$. The average value of weighted $K$ for the entire basin is 0.13 , which confirms the high susceptibility of the soils in the Bia watershed to water erosion. Vegetation plays a fairly good protective role over the majority of the Bia watershed since the value of $C$ equals 0.35 . The most sensitive areas of water related soil erosion, can deliver up to $1631 \mathrm{t} / \mathrm{ha} /$ year of materials. Our results are similar to those found by Payet et al. (2011) in southwestern Madagascar where they found values up to $1631 \mathrm{t} / \mathrm{ha} /$ year. At the watershed scale, 29.43 million tons of soil can potentially be removed and thus contribute to current sediment flow dynamics. This estimate therefore does not in any way predict the inflow to the lake from the Ayamé 1 hydroelectric dam, but provides information on the amount of material potentially supplied by the watershed and thus reveals its current alteration. The rate of erosion in the fragile Rif zones averages $17 \mathrm{t} / \mathrm{ha} /$ year according to Moukhchane et al. (1998). These different results are very close to those obtained by this study (16t/ha/year), which shows the relative reliability of the model applied. Hasbaia et al. (2012) explains the soil loss by the poor vegetation cover, by the vulnerability of the soil to erosion due to high temperatures and by the high intensity of rainfall. The most significant findings of this study are that soil loss in the area is well beyond the tolerance limit and that crop factor is more important in influencing soil loss. Soil loss tolerance limit varies from 1 to $12 \mathrm{t} / \mathrm{ha}$ /year depending on climate (Roose, 1994). The very fact that soil loss has crossed the tolerance limit is a matter of concern because this is an area under agriculture. If soil erosion is allowed to continue at the present rate, there may be eventual degradation of land, decline in soil fertility and reduced yield of crops. The results of the study clearly indicate that soil erosion in the area should be a cause for concern. Under such circumstances it becomes increasingly relevant to adopt necessary soil conservation measures so as to ensure the prolonged fertility of the land and prevention of degradation of land quality. Thus, it can be said that the USLE is a very useful tool for predicting soil loss under African conditions, its main advantage being its simplicity

Data availability. The precipitation data is not publicly available due insitutions policy. The Shuttle Radar Topography Mission (SRTM) image of N05W004 coordinates, from 11 to 22 February 2000, from Space Shuttle Endeavour (STS-99), obtained from $\mathrm{ftp} / / /$ eosrp01u.ecs.nasa.gov/srtm/version1/15Africackbox/ (last access: 1 January 2021). Landsat ETMC images, scenes 195-056 and 195-055, 14 March 2003, provided by http://earthexplorer.usgs.gov/ ckbox/ (last access: 1 January 2021).

Author contributions. MNEH is responsable for data analysis and mansuscript writing. Others authors participate in data collection and analysis. 
Competing interests. The contact author has declared that neither they nor their co-authors have any competing interests.

Disclaimer. Publisher's note: Copernicus Publications remains neutral with regard to jurisdictional claims in published maps and institutional affiliations.

Special issue statement. This article is part of the special issue "Hydrology of Large River Basins of Africa". It is a result of the 4th International Conference on the "Hydrology of the Great Rivers of Africa”, Cotonou, Benin, 13-20 November 2021.

Acknowledgements. We would like to thank the IAHS SYSTA award for providing us with a financial support to attend the 4th International conference on the "Hydrology of the Great Rivers of Africa”, Cotonou, Benin,13-20 November 2021.

\section{References}

Arnoldus, H. M. J.: An approximation of the rainfall factor in the USLE, Assessment of Erosion, Wiley, Chichester, England, 127132, 1980.

Desmet, P. J. J. and Govers, G.: Comment on "Modelling topographic potential for erosion and deposition using GIS", International Journal of Geographical Information Science, 11, 603610, https://doi.org/10.1080/136588197242211, 1997.

Durigon, V. L., Carvalho, D. F., Antunes, M. A. H., Oliveira, P. T. S., and Fernandes, M. M.: NDVI time series for monitoring RUSLE cover management factor in a tropical watershed, Int. J. Remote Sens., 35, 441453, https://doi.org/10.1080/01431161.2013.871081, 2014.

Gitas, I., Douros, K., Minakou, C., Silleos, G., and Karydas, C.: Multi-temporal soil erosion risk assessment in N. Chalkidiki using a modified Usle raster model, EARSeL eProceedings, 8, 4053, 2009.

Hasbaia, M., Hedjazi, A., and Benayada, L.: Variability of water erosion in the Hodna basin: case of the Elham wadi subwatershed, Rev. Mar. Sci. Agron. Vét., 1, 28-32, 2012.
Kouassi, K. L., Kouamé, K. I., Konan, K. S., Angoulo, M. S., Demé, M., and Meledje, N. E. H: Two-Dimensional Numerical Simulation of the Hydro-Sedimentary Phenomena in Lake Taabo, Côte d'Ivoire, Water Ressources Management, Water Resour. Manage., 27, 4379-4394, https://doi.org/10.1007/s11269-013-0417$\mathrm{x}, 2013$.

Kumar, B. J., Yu, I., and Jeong, S.: Estimation of Soil Erosion Using RUSLE Model and GIS Techniques for Conservation Planning from Kulekhani Reservoir Catchment, Nepal, Journal of Korean Society of Hazard Mitigation, 16, 323-330, https://doi.org/10.9798/KOSHAM.2016.16.3.323, 2016.

Moukhchane, M., Bouhlassa, S., and Chalouana, A : Approche cartographique et magnétique pour l'identification des sources de sédiments: cas du bassin versant Nakhla (Rif, Maroc), Sécheresse,3, 227-232, 1998.

Payet, E., Dumas, P., and Pennober, G.: Modélisation de l'érosion hydrique des sols sur un bassin versant du sud-ouest de Madagascar, le Fiherenana, VertigO, 11, https://doi.org/10.4000/vertigo.12591, 2012.

Raissouni, A.: Modeìlisation et cartographie de la sensibiliteì et de l'aleìa d'eìrosion des sols aÌ l'échelle régionale par USLE et SIG (Rif Nord occidental, Maroc), Theìse de Doctorat Es-Sciences, Fac. Sci. Tech. Tanger, Maroc, 208 pp., 2012.

Renard, K. G., Foster, G. R., Weesies, G. A., Mac Cool, D. A., and Yoder, D. C. (Eds): Predicting soil erosion by water: A guide to conservation planning with the Revised Universal Soil Loss Equation (RUSLE), Agric. Handb., number 703, U.S. Gov. Print. Office,Washington, DC., 383 pp., 1997.

Roose, E.: Introduction aÌ la gestion conservatoire de l'eau, de la biomasse et de la fertiliteì des sols (GCES), FAO Soils Bulletin, Rome, 70, 420 pp., 1994.

Shin, G. J.: The analysis of soil erosion analysis in watershed using GIS, Ph.D. thesis, Department of Civil Engineering, Gang-won National University, South Korea, 145 pp., 1999.

Stone, R. P. et Hillborn, D.: Universal Soil Loss Equation, Ontario, Canada, Ontario Ministry of Agriculture and Food (OMAFRA), [Enligne], http://www.giser.be/wpcontent/uploads/ 2012/05/USLE-infosCanada.pdf (last acces: 18 October 2021), 2000.

Wischmeier, W. H. and Smith, D. D.: Predicting Rainfall Erosion Losses, Agr. Han., 537, 285-291, https://doi.org/10.1029/TR039i002p00285, 1978. 